\title{
Evolving high altitude livelihoods and climate change: a study from Rasuwa District, Nepal
}

\author{
Douglas James Merrey ${ }^{1} \cdot$ Abid Hussain $^{2}$ (D) Deepak Dorje Tamang ${ }^{3} \cdot$ Bhuwan Thapa $^{4} \cdot$ Anjal Prakash $^{2}$
}

Received: 23 October 2017 / Accepted: 3 July 2018 / Published online: 23 July 2018

(C) The Author(s) 2018

\begin{abstract}
This study examined local people's perception of climate change and its impacts on their livelihoods, and identified key opportunities and threats arising in four Village Development Committees in the high mountains of Rasuwa District, Nepal. The local people are still heavily dependent on agriculture and livestock for their food security and livelihoods, despite the involvement of a significant proportion of households in non-agricultural income-generating activities, such as tourist services and labour work in other areas (outmigration). In agriculture, farmers mainly cultivate traditional food crops such as millets, buckwheat, local beans, and barley. They also cultivate rice, potato, and vegetables. Agriculture is mainly rainfed with a few exceptions of micro-irrigation systems fed by springs and snow-melt water. The impacts of climate change are mixed to date: changes in patterns of snowfall and snowmelt, rainfall, and temperatures are having both positive and negative impacts. Households are adapting to this changing climate through changes in their cropping patterns, integration of livestock with agriculture, and adoption of non-farm income activities. There are also new opportunities coming up at the study sites such as new markets for vegetables, traditional crops, and livestock.
\end{abstract}

Keywords High-altitude agriculture $\cdot$ Farmer-managed irrigation $\cdot$ Climate change $\cdot$ Opportunities $\cdot$ Nepal

\section{Introduction}

Around 240 million people live in the Hindu-Kush Himalayan (HKH) mountain areas (Rasul et al. 2018), the extent of which is about 3.4 million square kilometers (Shrestha et al. 2015). The livelihoods and food security of mountain communities depend heavily on local resources at all elevations, although specific agro-ecological and livelihood potentials vary considerably. Subsistence agriculture, livestock, and horticulture are the main sources of livelihood, with livestock becoming more important than arable farming at higher elevations (Hussain et

Abid Hussain

abid.hussain@icimod.org; abidwaqas670@ hotmail.com

1 Independent Consultant on Natural Resources Policy and Institutions, Gainesville, FL, USA

2 International Centre for Integrated Mountain Development (ICIMOD), Kathmandu, Nepal

3 SEARCH, Kathmandu, Nepal

4 School of Geography and Development, University of Arizona, Tucson, AZ, USA al. 2016). Remittances from those who have out-migrated, small businesses, wage labour, tourism, and the collection and sale of medicinal plants and other herbs also contribute to livelihoods and food security. However, in recent years, climatic and socio-economic factors have contributed to the depletion of the natural resource base across the HKH region (Rasul and Hussain 2015). Climatic changes include unprecedented changes in precipitation patterns and hydrological imbalances, rises in temperature, frequent floods and the degradation of forests, rangelands, and agricultural lands (Gentle and Maraseni 2012; Gawith et al. 2015; Pradhan et al. 2015; Aryal et al. 2016; Hussain et al. 2016).

Climate change is adding challenges to livelihoods of the mountain people. Temperatures in the high HKH mountains are increasing at a significantly faster rate than the global average, with much variation among river basins. Winters are seeing more warming than summers, and the highest mountain areas are generally the most affected (Shrestha et al. 2015). Precipitation across the HKH region is likely to increase on average by about $5 \%$ by 2050 , but with considerable variation among river basins (Shrestha et al. 2015).

Substantial losses of glacial mass and area are projected for most of the HKH region. The rivers originating in the mountains of the HKH region are among those those of the world 
which are most dependent on melting glaciers and snow (Lutz et al. 2014; Wiltshire 2014). According to Wiltshire (2014), the eastern Himalayan glaciers, e.g. those in Nepal and Bhutan, are considered among the most vulnerable to climate change, as snowfall decreases and ablation of glaciers increases with warming. These glaciers are projected to decline in area and volume despite increasing precipitation - more rain and less snowfall. Their projected rate of decline is similar to that found in other mountain regions (Bolch et al. 2012; Immerzeel et al. 2013).

Climate change also has impacts on the downstream areas in terms of increased incidence of floods, and competition for jobs, food, and accommodation induced by in-migration from mountain areas (Hussain et al. 2016). Those living immediately downstream from glaciers are most vulnerable to glacial changes, mainly through reduced reliability of local water resources and increased occurrence of hazards including outburst floods from glacial lakes (Shrestha et al. 2015, p.9).

Rural mountain people's well-being has deteriorated, and they are increasingly vulnerable to hunger. These trends are made worse by political and social marginality, inaccessibility, and impacts of climate change. Poverty is greater in the mountains, and the rate of poverty reduction is slower than in the lowlands, thus amplifying the differences between the two types of location (Hunzai et al. 2011; Gerlitz et al. 2012, 2015). Several studies have compared community members' perceptions of climate change and its impacts with measured data and found that they are generally quite consistent (e.g. Aryal et al. 2016; Sujakhu et al. 2016).

In the high altitude mountain areas of Nepal such as Rasuwa District, the livelihoods of the people are heavily dependent on agriculture, livestock, and tourism (McVeigh 2004). Agriculture is highly vulnerable to climate change due to varying patterns of precipitation and glacier melting. Agriculture in Rasuwa districts is dominated by traditional crops such as buckwheat, millets, local beans, and pulses (Adhikari et al. 2017). In livestock, 'mountain cattle', i.e. yak, and yak-cattle hybrids (chauri) dominate the herds, though cows, sheep, and goats are also found in the area (McVeigh 2004).

Agriculture is mainly subsistence, with low yields; households rarely grow enough for more than a few months' supply for the year. Livestock is a far more important source of income for most. Pastoralism is the major source of cash, and provides a buffer against the highly variable tourism trade. Animals are taken to high mountain pastures in the summer, and brought to lower pastures in the winter: it is therefore a 'transhuman' grazing system.

Many studies of local perceptions of climate change and its impacts, the vulnerability of people to these changes, and their adaptations have recently been published (e.g. Chaudhary et al. 2011; Macchi et al. 2011; Manandhar et al. 2011; Chhetri et al. 2012; Gentle and Maraseni 2012; Shrestha et al. 2012;
Baul et al. 2013; Kusters and Wangdi 2013; Holmelin and Aase 2013; Aryal et al. 2016; Pradhan et al. 2015; Wang et al. 2016). These studies found that households perceived changes in climate and reported the increased incidence of climate related hazards such as floods, droughts, landslides, livestock diseases, crop pests, erratic rainfall and temperature extremes. Households also perceived that climate related hazards were significantly influencing agricultural production, income and household food security.

Several studies have compared community members' perceptions of climate change and its impacts, using quantitative data, and have found they are generally quite consistent (e.g. Aryal et al. 2016; Sujakhu et al. 2016). Our literature review found that communities have low capacities to respond to the impacts of climate change (e.g. Gentle and Maraseni 2012; Gawith et al. 2015), and they are not able to take advantage of opportunities emerging from climate change. They still need external support and assistance to do so (Gawith et al. 2015). In a broader, systematic review of the literature on community-based adaptation to climate change, McNamara and Buggy (2017) arrived at a similar conclusion: a greater focus is required on facilitating learning within and among communities from adaptation experiences, on supporting long-term adaptation strategies, and on promoting innovation and critical analyses of experiences.

This growing body of scientific studies is helping us to understand the current and likely future impacts of climate change on mountain people, what adaptation strategies are pursued by local communities and their level of success, and what kinds of policies, institutional arrangements and infrastructure investments will be needed to cope with changing water regimes. Nevertheless, there are still gaps in our knowledge. For example, many regions of the high altitude mountain areas such as Rasuwa District in Nepal have not been studied. Filling this gap in our knowledge is important, because communities' adaptation strategies and their outcomes vary significantly, and so, adaptation strategies will have to be designed accordingly. Therefore, the general objective of this study (see specific objectives in Table 7) is to document local people's perceptions of and responses to climate change, and its impacts on high-altitude agriculture, food security and livelihoods in Rasuwa District, Nepal.

\section{Methodology}

\subsection{Study area}

The study area is in Rasuwa District, a rugged, high mountain region of central Nepal. More than $60 \%$ of the district is over $3000 \mathrm{~m}$ above mean sea level, and many areas have no road access (Tamang 2016). The roads that do exist are rough and poorly maintained. Rasuwa was one of the worst-affected 
districts by the earthquakes that occurred in April and May 2015 (Rasul et al. 2015). There are almost no data on rainfall, temperature, and soils in the higher regions of Rasuwa, except for some recent measurements in the Langtang river basin (e.g. Immerzeel et al. 2014). In general, the hottest periods are during the pre-monsoon and monsoon periods; the southwest monsoon from mid-June to September produces most of the annual rainfall. Rainfall, snowfall as well as temperatures vary considerably, according to altitude. In Rasuwa District, most people are Tamang, have been in the area for at least 300 years and are of Tibetan origin (McVeigh 2004).

The district is situated in the North-West part of the Central Development Region, about 120 km North from Kathmandu, the capital city of Nepal (Neupane and Devkota 2017). Based on preliminary information, five specific sites, Gatlang, Goljung, Chilime, Thuman, and Grey, were identified for indepth field data collection (Fig. 1). The first four are Village Development Committees (VDCs), whereas the last is a hamlet of Gatlang VDC.

The altitude of these sites varies from 1700 to $2600 \mathrm{~m}$ above mean sea level (Table 1). This variation provided wide scope for examining the differences in irrigation systems, agriculture, and livelihoods of local people.

Our researchers visited agricultural fields and irrigation systems to observe cropping patterns and water management practices at three study sites. Lack of time precluded visiting Grey and Thuman; informants from those communities met us in Syabrubesi town situated in Syafru VDC (Fig. 1).

\subsection{Data collection and analysis}

Our study collected data in 6 days (18-23 September 2016) following qualitative methods such as focus group discussions (FGDs), key informant interviews, and observations to study the nuances of climate change from peoples' perspectives indepth (Table 1). We also drew on some case studies. The indepth qualitative investigation of climate change has become a major field in the past decade (Crate and Nuttall 2009; Rudiak-Gould 2011).

This study was designed exclusively as an in-depth qualitative study. No standardized questionnaire or structured checklists were prepared. Rather, it was planned to just prepare a guiding tool (coordination schema) which only directs the research with broader aspects around which in-depth discussions may be initiated with the focus groups through simple open ended questions. FGDs were conducted in such a way that community groups had maximum freedom to express their views in detail about the key aspects presented in the coordination schema (Appendix Table 7). During the discussions, the researchers kept asking the follow up questions emerging mainly from the details provided by the respondents. These helped researchers considerably to understand the issues in depth. Some interviews with key informants were also arranged to cross-check the information collected during FGDs. Community groups for FGDs and local key informants were identified through a local NGO. They contacted the local people who had sufficient experience of farming and
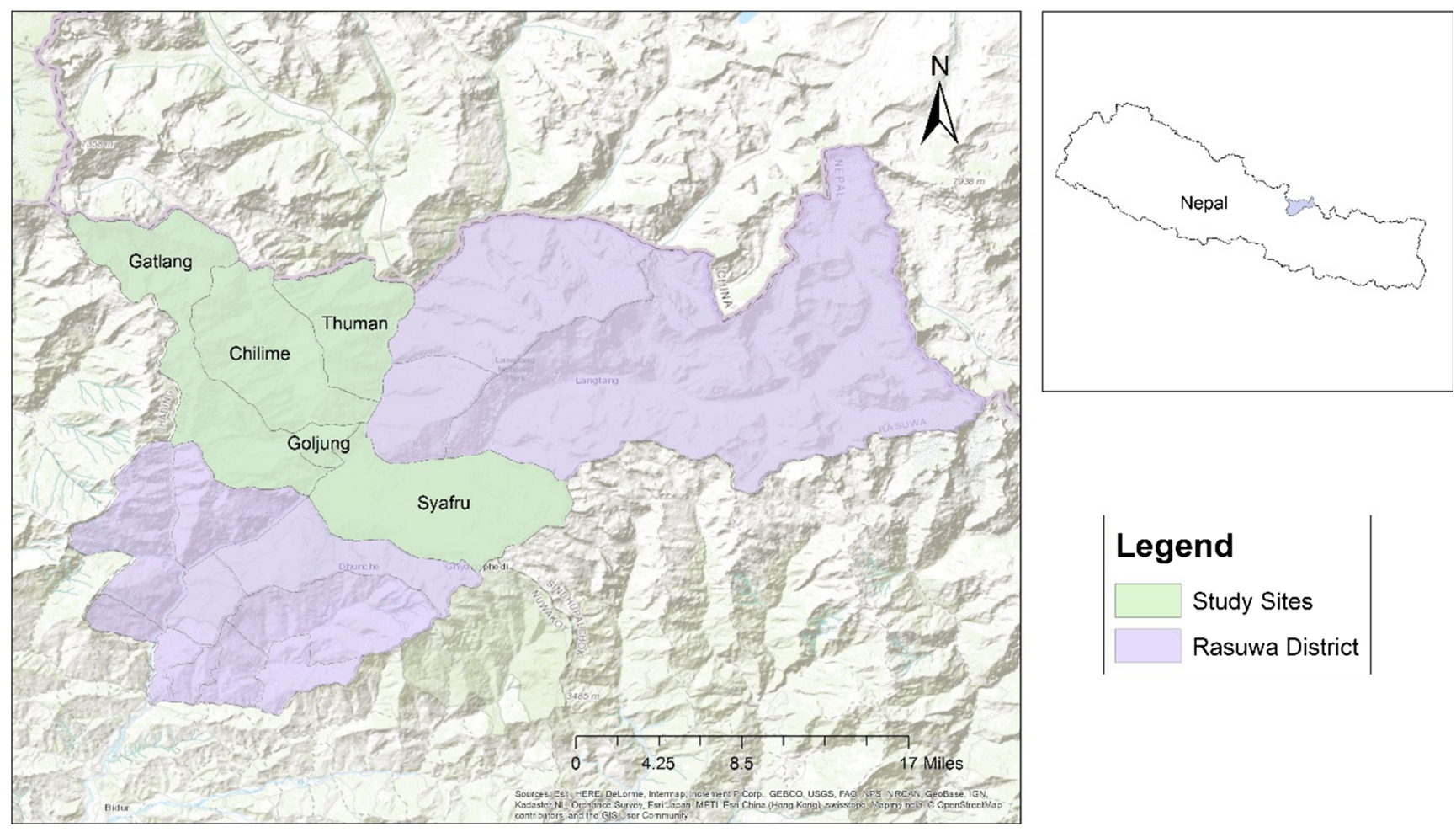

Fig. 1 Study sites in Rasuwa District, Nepal 
Table 1 Rasuwa district study sites and data collection tools

\begin{tabular}{|c|c|c|c|c|c|c|}
\hline \multicolumn{2}{|l|}{ Indicators/tools } & Gatlang & Goljung & Chilime & Thuman & Grey \\
\hline \multicolumn{2}{|c|}{ Height (above mean sea level) ${ }^{\mathrm{a}}$} & $2500 \mathrm{~m}$ & $1800 \mathrm{~m}$ & $1700 \mathrm{~m}$ & $2600 \mathrm{~m}$ & $1750 \mathrm{~m}$ \\
\hline \multicolumn{2}{|l|}{ Administrative status } & VDC & VDC & VDC & VDC & $\begin{array}{l}\text { Hamlet (Wards } 7 \& 8 \text { ) } \\
\text { of Gatlang VDC }\end{array}$ \\
\hline \multirow[t]{3}{*}{ Focus group discussions } & Total participants ${ }^{\mathrm{b}}$ & 4 & 5 & 18 & 3 & 4 \\
\hline & Male participants ${ }^{\mathrm{b}}$ & 4 & 1 & 17 & 2 & 1 \\
\hline & Female participants ${ }^{\mathrm{b}}$ & 0 & 4 & 1 & 1 & 3 \\
\hline \multicolumn{2}{|c|}{ Interviews with key informants } & $\begin{array}{l}\square 1 \text { interview in } \\
\text { cheese factory } \\
\text { established by } \\
\text { Dairy } \\
\text { Development } \\
\text { Corporation } \\
\text { (DDC), Nepal } \\
\square 2 \text { interviews } \\
\text { with local } \\
\text { community } \\
\text { representa-- } \\
\text { tives }\end{array}$ & $\begin{array}{l}\square 1 \text { interview with } \\
\text { local } \\
\text { community } \\
\text { representatives }\end{array}$ & $\begin{array}{l}\square 1 \text { interview with } \\
\text { users of Dalang } \\
\text { Irrigation } \\
\square 2 \text { inter-views } \\
\text { with } \\
\text { representatives } \\
\text { of local } \\
\text { vegetables } \\
\text { production } \\
\text { groups and } \\
\text { local youth } \\
\text { group }\end{array}$ & $\begin{array}{l}\square 1 \text { interview } \\
\text { with local } \\
\text { community } \\
\text { representa- } \\
\text { tives }\end{array}$ & $\begin{array}{l}1 \text { interview with } \\
\text { local community } \\
\text { representatives }\end{array}$ \\
\hline \multicolumn{2}{|l|}{ Field observations } & \multicolumn{5}{|c|}{ We observed the cropping systems, water sources, and micro-irrigation systems. } \\
\hline \multicolumn{2}{|c|}{ Key informant interview at district level } & \multicolumn{5}{|c|}{$\begin{array}{l}\text { We conducted interviews with key informants at district headquarter Dunche from the Irrigation Office } \\
\text { and District Agriculture Development Office (DADO). }\end{array}$} \\
\hline
\end{tabular}

${ }^{a}$ Altitude information provided by District Agriculture Development Office (DADO)

${ }^{\mathrm{b}}$ counted by researchers during discussion meetings

information on non-farming activities to provide the required information relevant to being able to make a comparison to with situation 10 years earlier. Additional information from a cheese factory (in Gatlang) and a vegetable production and marketing group (Chilime) was collected by interviewing key informants. Key informants were selected for interview because it was possible to gather all members on short notice due to rainy weather and other engagements of group members. Researchers also interviewed key informants from the Irrigation Office and District Agriculture Development Office (DADO) in the district headquarters in Dunche.

The results are mainly based on qualitative information. However, some descriptive statistics such as averages and percentages have also been used to support the qualitative analysis. Some descriptive statistics (Tables 2 and 6, Boxes 1 and 2) were provided by community groups and key informants. For example, during data collection community respondents and key informants provided approximate numbers, which were then converted to percentages.

\section{Findings}

\subsection{Socio-economic characteristics of study sites and food security status}

In Rasuwa District 43,300 persons were living in 9778 households, according to the 2011 Census. The average household size was, therefore, about 4 persons. The proportion of women and men in the district was 49.6 and $50.4 \%$, respectively. The proportion of women in the study sites was similar to the district average (NPHC 2011). The sites have lower population densities than most VDCs in the district. Most of the population is ethnically Tamang (NPHC 2011).

The area was severely affected by the earthquakes in April and May 2015. In Gatlang, for example, many houses had not yet been reconstructed at the time of our visit. Many people were found still living in temporary, sheet metal houses. There were also many NGO offices in the village.

The average landholding size in the study sites varied from 10 ropanis $(0.5 \mathrm{ha})$ to 16 ropanis ( $0.8 \mathrm{ha}$ ) (Table 2$)$. In general, farms are small and agriculture is practiced mainly to meet domestic food requirements. However, many people also earn significant incomes from agriculture and livestock. There were also some cases of commercial farming and collective marketing activities. Most agriculture depends on rainfall (Table 2), but in Chilime, Thuman, and Grey, there were small farmer-managed irrigation systems that enabled farmers to diversify their crops. For drinking and other domestic purposes, households largely depended on spring water.

At the study sites, people also depended on nonagricultural income sources such as tourist services and remittances (Table 2). A local cheese factory in Gatlang, hydropower station in Chilime, and handcrafts in Goljung and Thumen were additional sources of local livelihoods. In Gatlang, around 10\% households were involved in providing tourist services, including 
Table 2 Socio-economic characteristics of study sites

\begin{tabular}{|c|c|c|c|c|c|}
\hline Characteristics & Gatlang & Goljung & Chilime & Thuman & Grey \\
\hline Number of households & 400 & 269 & 340 & 239 & 180 \\
\hline Average landholding size ${ }^{a}$ & 12 ropanis & 12 ropanis & 12 ropanis & 16 ropanis & 10 ropanis \\
\hline Main income sources & $\begin{array}{l}\text { Agriculture } \\
\text { Livestock } \\
\text { Tourist services } \\
\text { Remittances } \\
\text { Employment at local } \\
\quad \text { cheese factory }\end{array}$ & $\begin{array}{l}\text { Agriculture } \\
\text { Livestock } \\
\text { Tourist } \\
\quad \text { services } \\
\text { Remittances } \\
\text { Handcrafts }\end{array}$ & $\begin{array}{l}\text { Agriculture } \\
\text { Livestock } \\
\text { Tourist services } \\
\text { Local labour and } \\
\text { employment } \\
\text { at hydro power } \\
\text { station }\end{array}$ & $\begin{array}{l}\text { Agriculture } \\
\text { Livestock } \\
\text { Tourist services } \\
\text { Remittances } \\
\text { Handcrafts }\end{array}$ & $\begin{array}{l}\text { Agriculture } \\
\text { Livestock } \\
\text { Remittances } \\
\text { Local labour }\end{array}$ \\
\hline$\%$ households with out-migrants & $50-55 \%$ & $15-20 \%$ & $<5 \%$ & $10-15 \%$ & $20-25 \%$ \\
\hline Main source of water for agriculture & Rainfed & Rainfed & $\begin{array}{l}\text { Rainfed \& partly } \\
\text { irrigated }\end{array}$ & $\begin{array}{l}\text { Rainfed \& partly } \\
\text { irrigated }\end{array}$ & $\begin{array}{l}\text { Rainfed \& partly } \\
\text { irrigated }\end{array}$ \\
\hline Main source of water for drinking & Spring \& lake & Spring & Spring & Spring & Spring \\
\hline Labour shortages faced in agriculture & Yes & Yes & Yes & Yes & Yes \\
\hline
\end{tabular}

Source: Field notes

${ }^{a} 19.65$ ropanis equals one hectare

homestays, food, and guiding trekking for tourists. Men from eight households (2\% of total households) were employed in the local cheese factory. In Goljung and Thumen, women operated small cottage handcraft businesses such as making and selling traditional caps, carpets, shawls, and sweaters.

In Gatlang, currently, almost $50 \%$ of households have sent migrants to other parts of Nepal (Table 2), particularly Kathmandu, and overseas to search for opportunities to earn more income. Nearly $20 \%$ of all migrant sending households here sent workers overseas. In Goljung, Thuman, and Grey, 15-25\% households have sent migrants to other parts of the country and overseas. Among migrant sending households, only 4-5\% households in Goljung, and 30\% both in Thuman and Grey sent migrants overseas, mainly to Malaysia. Outmigration has declined significantly in Thuman VDC because of new job opportunities after opening of the Rasuwa-Kerung point of entry at the Nepal-China border, a growing business port. The Tamang Heritage Trail, a new trekking route, also passes through Thuman village, increasing revenue from tourist services. Of all the study sites, Chilime VDC has the lowest rate of out-migration. Besides, out-migrants are returning to the area because of employment opportunities at a local hydro-power station, and in vegetable farming and the tourist industry. There are also several guest houses and resorts in Thambuchet village of Chilime VDC, where employees of the power station and tourists stay, as well as some shops.

Despite the income from the (high) out-migration and other non-farm income activities, a significant proportion of households in the study sites still mainly depends on agriculture and livestock for their food security and livelihood. In Gatlang, this is the case with almost $70 \%$ of the households. As per the assessment (mid-November 2015 to mid-March 2016) of Nepal Food Security Monitoring System, Gatlang, Goljung and Thuman VDCs were categorized as 'stressed areas' in terms of food insecurity level i.e. these study areas are highly vulnerable to food and nutrition insecurity (GoN-WFP 2016). An aggregated assessment of two VDCs, Gatlang and Chilime, showed that $46 \%$ of the population in these VDCs faced food poverty, and half of the children under 5 years of age were stunted (Table 3). Likewise, the prevalence of wasting and underweight was, respectively, 14 and $37 \%$ in children below 5 years of age. Food poverty and malnutrition in Gatlang and Chilime VDCs was significantly greater than the average for the Rasuwa district (Table 3).

\subsection{Agriculture and livestock}

Households cultivate traditional food crops such as local maize, millets, buckwheat, local beans, lentils, and barley (Table 4), which are rich in micronutrients (Adhikari et al. 2017). This is understandable, since high mountain areas are more suitable for these climate-resilient traditional crops than rice and vegetables. However, farmers also cultivate potato and other vegetables as food and cash crops (Table 4). During the peak tourist season (April-June), tourists staying in these areas are served with dishes prepared from these traditional food crops. Although they are mainly cultivated for home consumption, surplus produce is sold at the markets of Chilime, Saybrubesi, Dunche, and Kathmandu.

Gatlang and Thuman are high-altitude VDCs (Table 1), which are more suitable for traditional food crops. In Thuman, livestock is more important than crops for income generation. In Gatlang, the main income-generating crops are potato, barley, and local species of beans. Farmers reported that, on average, each household sells 40 bags of potato $(50 \mathrm{~kg} / \mathrm{bag})$ every year, resulting in an approximate gross income of Rs. (Nepali 
Table 3 Food security in study areas: example of Gatlang and Chilme

\begin{tabular}{lllll}
\hline Area & $\begin{array}{l}\text { Prevalence } \\
\text { of food } \\
\text { poverty }\end{array}$ & $\begin{array}{l}{ }^{\mathrm{a}} \text { Prevalence } \\
\text { of stunting } \\
(\%)\end{array}$ & $\begin{array}{l}{ }^{\mathrm{a}} \text { Prevalence } \\
\text { of wasting } \\
(\%)\end{array}$ & $\begin{array}{l}{ }^{\mathrm{a}} \text { Prevalence } \\
\text { of } \\
\text { underweight } \\
(\%)\end{array}$ \\
\hline${ }^{\mathrm{b}}$ Gatlang \\
and \\
$\begin{array}{c}\text { Chilime } \\
\text { Rasuwa } \\
\text { district }\end{array}$ & 46 & 49 & 14 & 37 \\
\hline
\end{tabular}

Source: Haslett et al. 2014

${ }^{\text {a }}$ In children under 5 years of age

${ }^{\mathrm{b}}$ Aggregated food and nutrition security assessment of two VDCs

Rupees) 53,000 (US\$ 500) per annum at a price of Rs 23-28/kg [US\$ 0.22-0.26]). Likewise, households earn a good income from local beans and barley, ranging from Rs 15,000-25,000 (US\$ 142-236) per annum per household.

Notably, all agricultural production is organic - no artificial fertilizers or pesticides are used and most of it depends on rainfall for water and animal power for ploughing. Therefore, production costs are low and in the form of family labour and homekept seed. All types of agricultural activities, except ploughing, are usually done by female members of the household.

In Gatlang, local people reported that the high outmigration rate has resulted in labour shortages in agriculture with an increase in the agricultural labour burden on women. However, such labour shortages are not reported from other study sites. In Gatlang, some farmers are cultivating vegetables such as tomato and cucumber in plastic tunnels. In total, ten plastic tunnels were observed, all constructed with external support from NGOs after the April 2015 earthquake. One female tunnel farmer reported that none of the tunnel farmers were producing vegetables for a commercial purpose. They are mainly consuming them locally.

In Grey, too, mainly traditional food crops are being cultivated. However, some farmers also grow vegetables such as cauliflower and potato. The farmers' group reported that around $20 \%$ households mainly depend on agriculture for their food security and livelihood.

Goljung, situated at a lower altitude (1800 $\mathrm{m}$ above mean sea level; Table 1), is also suitable for rice cultivation. Some traditional high-altitude crops such as buckwheat, barley, and finger millets are not grown in this area. Nearly $20 \%$ of agricultural land remains fallow due to the lack of a functional irrigation system and labour shortages during the critical periods of sowing.

In Chilime, the presence of a small-scale irrigation system provides more flexibility and a greater range to farmers in terms of the type of crops they cultivate. Thanks to a good water supply for agriculture, rice is grown on 127 roans $(6.5 \mathrm{ha})$. In addition, potato, barley, millets, and vegetables are cultivated. Among the vegetables, carrot, cucumber, radish, chilli, spinach, cabbage, cauliflower, onion, and garlic are income-generating crops together with rice, black lentils, and potato.

In view of the income potential from vegetable production, some local people established a vegetable production group in Thambuchet, the headquarters of Chilime VDC (Box 1).

Box 1 Vegetable Production and Marketing Group in Thambuchet

A discussion with a vegetable production and marketing group (VPMG) was organized to explore the potential of vegetable production and income in the Chilime VDC. This VPMG includes 32 households, and is collectively marketing their vegetables locally and in other areas such as Syabrubesi and Dunche. The group wants to make Chilime a centre for vegetable cultivation. They highlighted the economic benefits of collective production and marketing activities, giving tomatoes as an example. The group sold tomatoes at a price of Rs $100-120 / \mathrm{kg}$ (US\$ $0.94-1.13$ ) to markets with better prices. This is $2-3$ times higher than the normal price individual farmers get from middlemen. The group grows radish, carrot, cucumber, cabbage, cauliflower, spinach, and red chili. The male members recognize the need to have more women's participation in their group, as they say they value gender equality and social inclusion. They plan to buy a small delivery van for delivery of vegetables to the market. A collection centre for vegetables is also going to be established by this group in Thambuchet.

Livestock is also an important source of food and income. In Gatlang, chauri is the most important livestock for this high-altitude area because of its resilience to severe cold and fodder stress. Households have constructed 40 small shelters for chauri and yak herds in the high-altitude areas of the VDC, where at least 40 male members of households stay to take care of livestock. They bring chauri/yaks to the nearby Sangen pasture for grazing. (Sangen is a big pastureland that extends into Tibet and is shared by Gatlang, Goljung, and Grey settlements.) This is one reason why female members must carry out agricultural work in the absence of male members. During the winter months, snow covers the pasture lands, and households use dried crop residues as fodder for livestock. Chauri are a good source of income for households (See Box 2).

\section{Box 2 Income from Sale of Chauri Milk in Gatlang}

The Dairy Development Corporation (DDC) of Nepal established a cheese factory in Gatlang in 1977. This factory is still operating and providing a good income to local livestock farmers. The factory produces $9000-11,000 \mathrm{~kg}$ of cheese and $3000 \mathrm{~kg}$ of butter per annum. This requires the supply of nearly 90,000 L of milk per annum from Gatlang livestock farmers. Farmers are not only meeting this milk demand but also saving sufficient milk for family consumption. The price of milk is determined by the factory, based on the fat content of the milk. On average, Rs. (Nepali Rupees) 54/L (US\$ 0.51) is being paid to milk suppliers. Overall, 40 chauri farmers supply almost $250 \mathrm{~L}$ of milk per day to the factory, and per household the annual gross income from milk sales is nearly Rs. 121,500 (US\$ 1146). Thus, chauri farmers earn over Rs 10,000 (US\$ 94) per month from the sale of milk. 
In Thuman, biophysical and agro-ecological conditions are similar to those in Gatlang. However, in addition to chauri and goat, households raise cow, sheep, and buffalo. They sell live animals to markets in Syabrubesi. Chauri farmers sell their surplus milk for about Rs 50-55/1 (US\$ 0.47-0.52) to the private cheese factory there.

In Goljung and Grey, chauri/yak are not part of the livestock mix, as they are high-altitude livestock requiring large pasturelands, mostly found at altitudes of $2500 \mathrm{~m}$ or above (Table 4). In Grey, there is also a District Development Committee milk collection centre to which cow farmers sell their surplus milk.

\subsection{Water resources and irrigation systems}

Rasuwa District, situated in the wet mountain ranges of Nepal, is rich in water resources in terms of springs, snowmelt water, glaciers, and rainfall. These create numerous small streams and feed several large rivers (Chilime, Trishuli). At the study sites, the sources and amounts of water (rainfall and snow) are broadly similar, but their use and management vary significantly. This section explores the similarities and differences across the five study sites.

The first three sites, Gatlang, Goljung, and Chilime VDCs, share a common watershed.

\subsubsection{Gatlang}

In Gatlang, the main water source is the Parvati Kunda (small lake or pond), which is located at an altitude of $2610 \mathrm{~m}$ above mean sea level. This pond is situated at a higher attitude than the Gatlang settlement and its agricultural fields. It is fed by water from four springs as well as snowmelt and rainfall in its catchment area. In Winter, the watershed is covered with snow for 3 months (December-February); the pond receives snowmelt water from February to April.

The pond has cultural and religious significance and many people come to it for festivals throughout the year. Pipes constructed by individuals and the village carry drinking water from the pond to them. A ferro-cement tank was constructed below the pond, but above Gatlang village, to store drinking water. The extra water from the pond flows through the village. This water is also used for livestock and to operate water mills for grinding cereals. Only three mills still operate, a reduction from the six that had been operating earlier. This may reflect a reduction in the flow of water.

Water from this pond is currently not being used for agriculture in Gatlang. Local farmers believe that there is a huge potential to use this water for irrigation to diversify cropping systems, but at present, they say they are not interested in doing this. They said that the water requirements of their current cropping systems, mainly traditional crops, were adequately met by rainfall and snowfall. They also reported that 
they could cultivate rice in the lower areas of the village if they had an irrigation system, but it would be more feasible to continue traditional cropping because the agro-ecology of the area suits these crops. They are resilient to cold waves and water stress, and do not require inorganic fertilizers.

There is also potential to use the pond water for raising trout, a profitable enterprise. But the religious significance of the Parvati Kunda precludes this and may also be a factor in the lack of interest in irrigation. Speculatively, this religious belief may also serve to limit over-exploitation of the stream, which would otherwise affect the downstream communities (e.g., Goljung and Chilime).

\subsubsection{Goljung}

In Goljung, drinking water comes from springs. After the 2015 earthquakes, there was a shortage of drinking water because some springs dried up due to seismological impacts. However, after the 2015 and 2016 monsoons, these springs are flowing again.

A small-scale irrigation system was constructed in 1990 with the support of the District Development Committee (DDC) under the Ministry of Local Development. After operating for a year, the main canal was damaged by road construction related to the construction of the Chilime hydropower dam. There were some political issues which prevented its rehabilitation, and the community members failed to obtain support from either the hydropower project or the government to get it repaired. However, they continued their efforts to have the irrigation system rehabilitated. The Irrigation Department recently undertook a detailed feasibility study and approved this project to be implemented in 2017. When completed, the system would irrigate 1500-2000 ropanis (76.5-102 ha).

Two rivers, the Gatlang and the larger snow-fed Sangen, flow into the hydropower reservoir. Diverting water to their irrigation system may reduce the dry season flow in the reservoir somewhat. Even without this irrigation system, Goljung farmers cultivate a variety of crops, and have also resurrected their traditional, non-agricultural, income practices, particularly handcrafts, to support their livelihoods.

\subsubsection{Chilime}

In Chilime, there is also a small-scale irrigation system, the Dalang Irrigation System, in Wards 2 and 3 of the VDC. A focus group discussion with members of the water user association was organized to investigate water and governance issues in detail. A canal was built using concrete in 1991 with support from the Department of Irrigation. The system irrigates about 127 ropanis ( $6.5 \mathrm{ha}$ ) of land operated by 30 households. There is a small canal that carries water from two temporary dams constructed in the river using stone and gravel in upstream areas. These small dams are fed by both the
Bemdang River and Paravti Kunda (also known here as Gatlang Khola).

The system is currently not registered with any government agency and is managed informally by the farmers. They cultivate a wide range of cereals and vegetables (Table 4), but face water shortages during the winter months (DecemberFebruary). They reported that the water flow increased significantly in March-May, which shows the system is fed by snowmelt water.

Farmers maintain the system through collective action: they clean and repair the dam and canals together, particularly in mid-June because during this period they all need water at the same time to cultivate rice. They do not collect funds for maintenance but users contribute labour. On average, each household that cultivates rice, contributes 2 days of labour. When major maintenance is required, they seek external funding from the VDC, the Chilime hydropower project, or other sources. In the past, the hydropower company provided some financial support for rehabilitation of the system.

There is no formal mechanism for water distribution among the farmers. Everyone tries to get water simultaneously during critical periods. The fields located at the tail end of the canal face water shortages, and occasionally there are conflicts. Farmers reported they try to resolve such conflicts through mutual discussion and a decision to allocate water to head and tail farmers following an agreed time schedule. For example, tail farmers may be given the right to use water during day time, and head farmers during the night. It may also be the other way around.

\subsubsection{Thuman}

In Thuman VDC, all 250 households are involved in agriculture and livestock raising. They cultivate local rice and other crops (Table 4). The main source of water for agriculture is rainfall. There are also small-scale irrigation systems, which are mainly fed by spring water and irrigate approximately 1200 ropanis (61 ha) of land. The irrigation water is mainly used for rice cultivation. For other crops, such as lentils, barley, millets, potato, and local beans, farmers rely on rainfall.

\subsubsection{Grey}

Grey also had an irrigation system; it was constructed by the DDC around 20 years ago. It did not function because of community conflict and faulty alignment of the main canal. For example, when water was required to irrigate the rice fields on the lower terraces, the upstream farmers refused to allow the water to flow through. Farmers reported that such conflicts have been very frequent over the years. Currently, rice fields in Grey are irrigated from a nearby river source 
through a high-density polyethylene (HDPE) pipe. This pipe system irrigates nearly 100 ropanis (5.1 ha) of agricultural land and is operated by 15 households.

There is still no formal water distribution system, and sometimes there are conflicts over water. The group highlighted one key point: open, canal-based irrigation systems are not sustainable in Grey and other steep mountain areas. They are too vulnerable to damage from landslides and erosion during the monsoon. Closed, pipe-based irrigation systems are more sustainable and reliable - a point confirmed by the District Irrigation Engineer in Dhunche. These pipes can also be moved to other areas if necessary.

\subsection{Local people's perception of climatic variability and change}

At all study sites, local people had perceived changes in climate over the past 10 years (Table 5). In Gatlang, people reported they had observed changes in precipitation patterns over time. Ten years earlier, the village used to receive higher snowfall, both in frequency and amount. People also reported an increase in the incidence of erratic rainfall events, particularly in 2004-2014. However, rainfall patterns were considered 'normal' in 2015 and 2016. People also had observed that winters are now colder and summers warmer than 10 years ago.

In Goljung, people noticed more variability in rainfall patterns and increased incidence of erratic events. They also perceived an increase in the number of foggy days in winter over the last 10 years, and an increase in the number of hailstorms. Similar to Gatlang and Goljung, people in Chilime also reported changes in rainfall patterns and temperature over time. Summers are hotter and winters colder. In the last 18 years, they observed only two snowfall events, both in the same year. In Thuman, people perceived changes in rainfall patterns, and reported hotter summers and colder winters than 10 years before. In Grey, local people reported an increase in the incidence of erratic rainfall.

\subsection{Perceived impacts of climatic variability and change, and coping and adaptation measures}

In Gatlang, people said they had not perceived any obvious change in the availability of water in Parvati Kunda during the last 10 to 15 years in response to climate change (Table 6). The productivity of potato and barley increased in the last 2 years (2015 and 2016). Local people attributed this improvement to more normal rainfall patterns. But before 2015, changes in rainfall patterns had resulted in a lower production of potato and barley, particularly during 2010-2014.

Over the years, farmers developed indigenous mechanisms to cope with short-term and inter-annual variability in climatic conditions. During periods of water stress, resulting from unpredictable rainfall, farmers mainly cultivated alternative food crops such as millets, local beans, and lentils. These crops require less water and are more resilient to water stress. They also earned income from these crops through sales to local resorts in Gatlang, Chilime and Syabrubesi.

As we have seen, migration is an important source of off-farm income for the mountain communities in Rasuwa. With increasing tourism and work opportunities in cities and abroad, around 30-40\% households have also started some off-farm work or business, e.g., being tourist guides, constructing resorts for tourists, and outmigration to city centres for work. This means migration has become an alternative source of income during periods of reduced agricultural production resulting from climatic stresses.

Besides, about ten farmers have started cultivating tomato and cucumber in plastic 'tunnels' (simple mini-greenhouses). They collect water from springs in water tanks and take it by gravity to the tunnels through small-diameter HDPE pipes. At present, tunnel production is for home use and tunnels are constructed primarily with support from NGOs to diversify income opportunities for villagers. However, people perceive this as a future option for coping with water variability. For this, they say, they need external support for the supply of plastic and other materials.

Table 5 Local people's perceptions of climate change

Key changes in climate perceived by the communities compared to situation 10 years before

\begin{tabular}{|c|c|c|c|c|}
\hline Gatlang & Goljung & Chilime & Thuman & Grey \\
\hline $\begin{array}{l}\text { - Change in snowfall patterns } \\
\text { - Winter is colder and summer is } \\
\text { hotter } \\
\text { - Change in rainfall patterns }\end{array}$ & $\begin{array}{l}\text { - Changes in rainfall patterns } \\
\text { - Prolonged dry spells } \\
\text { - Erratic occurrences of } \\
\text { hailstorms } \\
\text { - Increased number of } \\
\text { foggy days in winter }\end{array}$ & $\begin{array}{l}\text { - Changes in rainfall patterns } \\
\text { - Winter is colder and summer is } \\
\text { hotter } \\
\text { - No snowfall in last } 10 \text { years } \\
\text { (only two snowfall events in } \\
\text { last } 18 \text { years) }\end{array}$ & $\begin{array}{l}\text { - Changes in rainfall patterns } \\
\text { - Winter is colder and summer is } \\
\text { hotter }\end{array}$ & $\begin{array}{l}\text { - More erratic } \\
\text { rainfall } \\
\text { events }\end{array}$ \\
\hline
\end{tabular}

Source: Field notes 
Table 6 Perceived impacts of climatic variability and change on water resources, and coping and adaptation measures

\begin{tabular}{|c|c|c|c|}
\hline Sites & Water resources & $\begin{array}{l}\text { Perceived impacts of climatic variability and } \\
\text { change }\end{array}$ & Activities that support coping and adaptation \\
\hline Gatlang & $\begin{array}{l}\text { - Parvati Kunda (pond): } \\
\text { Water source for livestock and } \\
\text { households, drinking and other } \\
\text { uses. } \\
\text { - Rainfall: } \\
\text { Agriculture is mainly dependent } \\
\quad \text { on rainfall and snowfall }\end{array}$ & $\begin{array}{l}\text { - No obvious change perceived in the } \\
\text { availability of water in Parvati Kunda } \\
\text { during the last } 10 \text { to } 15 \text { years, despite } \\
\text { changes in precipitation patterns. } \\
\text { - Improved productivity of potato and barley } \\
\text { in last } 2 \text { years (2015 \& 2016). } \\
\text { - Reduced production of potato, particularly } \\
\text { from } 2010 \text { to } 2014 \text {, attributed to changes in } \\
\text { timing and intensity of rainfall. }\end{array}$ & $\begin{array}{l}\text { - Enhanced cultivation of traditional food crops such } \\
\text { as millets, local beans and lentils. These crops are } \\
\text { more resilient to water stress. } \\
\text { - Started non-agricultural income activities by } \\
30-40 \% \text { households. } \\
\text { - Cultivation of vegetables in plastic tunnels started } \\
\text { by } 10 \text { farmers with piped water irrigation } \\
\text { systems. } \\
\text { - Strengthened integration of livestock with } \\
\text { agriculture. }\end{array}$ \\
\hline Goljung & $\begin{array}{l}\text { - Rainfall: } \\
\text { Agriculture is fully dependent on } \\
\text { rainfall }\end{array}$ & $\begin{array}{l}\text { - Lower productivity of all crops, attributed to } \\
\text { variability in rainfall patterns and increased } \\
\text { incidence of hailstorms } \\
\text { - Reduced productivity of potato, attributed to } \\
\text { increased number of foggy days }\end{array}$ & $\begin{array}{l}\text { - Enhanced integration of livestock in local } \\
\text { production systems } \\
\text { - Started new off-farm income activities such as } \\
\text { weaving of woolen jackets, caps, and carpets }\end{array}$ \\
\hline Chilime & $\begin{array}{l}\text { - Rainfall: } \\
\text { Agriculture is mainly dependent } \\
\text { on rainfall water } \\
\text { - Small-scale irrigation system: } \\
\text { Dalang Irrigation System }\end{array}$ & $\begin{array}{l}\text { - Reduced crop productivity in areas where } \\
\text { agriculture is dependent on rainfall } \\
\text { attributed to changing rainfall patterns by } \\
\text { local people } \\
\text { - Increased availability of water in } \\
\text { micro-irrigation system during April and } \\
\text { May attributed to increased snow-melt in } \\
\text { hotter summers }\end{array}$ & $\begin{array}{l}\text { - Diversification of crops (e.g. more vegetables) in } \\
\text { response to increased availability of water } \\
\text { through irrigation } \\
\text { - Use of irrigation to buffer water shortages during } \\
\text { dry season } \\
\text { - Adoption of informal water rotation mechanism } \\
\text { among farmers based on needs during the water } \\
\text { stress period (mid Jan-Feb) }\end{array}$ \\
\hline Thuman & $\begin{array}{l}\text { - Rainfall: } \\
\text { Agriculture is mainly dependent } \\
\text { on rainfall water } \\
\text { - Small-scale irrigation system: } \\
\text { This irrigation system is fed by } \\
\text { spring water. Around } 100 \\
\text { households benefit from the } \\
\text { irrigation system and cultivate } \\
\text { rice }\end{array}$ & $\begin{array}{l}\text { - Reduced production of rice in those areas } \\
\text { where agriculture is dependent on rainfall } \\
\text { attributed to changing rainfall patterns } \\
\text { - Reported no impact of climate change on } \\
\text { water availability in irrigation system }\end{array}$ & $\begin{array}{l}\text { - Diversified production systems through } \\
\text { introducing less water consumptive crops such as } \\
\text { beans, millets, potato, and barley } \\
\text { - The use of irrigation system to buffer water } \\
\text { shortages during the dry season } \\
\text { - Strengthened livestock such as chauri/yak, sheep, } \\
\text { cattle, and goats }\end{array}$ \\
\hline Grey & $\begin{array}{l}\text { - Rainfall: } \\
\text { Agriculture is mainly dependent } \\
\text { on rainfall water } \\
\text { - Small-scale irrigation system: } \\
\text { An HDPE pipe based system fed } \\
\text { by a nearby river source } \\
\text { irrigates } 5.1 \text { ha of land held by } \\
15 \text { households }\end{array}$ & $\begin{array}{l}\text { - Reduced production of crops in those areas } \\
\text { where agriculture is dependent on rainfall } \\
\text { attributed to changing rainfall patterns } \\
\text { - Reported no impact of climate change on } \\
\text { water availability in irrigation system }\end{array}$ & $\begin{array}{l}\text { - Diversified production systems through } \\
\text { introducing less water consumptive crops such as } \\
\text { lentils, barley, millets, potato, and beans } \\
\text { - The use of irrigation system to buffer water } \\
\text { shortages during the dry season } \\
\text { - Strengthened livestock such as cattle and goats }\end{array}$ \\
\hline
\end{tabular}

Source: Field notes

In Gatlang, climate change has not had any severe impacts on pasturelands, and livestock production, particularly of chauri, has not been affected. This encourages the villagers to keep raising chauri, which is profitable, given the presence of the local cheese factory.

In Goljung, changes in rainfall patterns have negatively affected the productivity of almost all crops. Erratic hailstorm events also pose threats to crop productivity (Table 6). For example in 2016, a heavy hailstorm damaged standing crops, resulting in a reduction of the paddy production by nearly $30 \%$. An increase in the number of foggy days has had negative impacts on potato production and local livelihoods, because potato is the main cash crop.
There is also an increase in the incidence of pest attacks on crops. Local people attributed this to prolonged dry spells, because rainfall reduces pest attacks to some degree.

Similarly to Gatlang, to cope with the impacts of climate change, people are increasing their non-agricultural income activities, and strengthening the integration of livestock with production systems.

In Chilime, local people reported a decline in rainfed crop productivity (Table 6). This was attributed to changing rainfall patterns. In irrigation, the main water stress period is midJanuary to February (winter period), when there is snow in the mountains and less rainfall is received. There is an increase in water availability in the canal from mid-April to mid-May 
because of a higher snow melting rate in upstream areas. During the severest water stress period (mid-January to February), on the other hand, water in the system is barely sufficient for vegetable farming and the operation of a water mill. With increased availability of water for irrigation during the summer months, farmers diversify their crops through the integration of vegetables and rice.

In Thuman and Grey, local people reported a decline in crop productivity and attributed it to changing rainfall patterns. At both sites, farmers are cultivating traditional crops such as lentils, barley, millets, potato, and beans, which are more resilient to water stress (Table 6). They are also strengthening their livestock production as an income source, to compensate for the declining income from crops.

\section{Discussions and future directions}

In the Rasuwa district of Nepal, $41 \%$ of the population is facing food poverty, with $47 \%$ children below 5 years of age suffering from stunting. In the study areas, levels of food poverty and malnutrition is much higher than the average in the district (Table 3). Among study areas, Gatlang, Goljung and Thuman VDCs are categorized as 'stressed areas' in terms of food insecurity level by the Nepal Food Security Monitoring System (GoN-WFP 2016), meaning that they are highly vulnerable to food and nutrition insecurity. As is the case for many mountain communities in Nepal some are facing socioeconomic and climatic changes, causing impacts on agriculture, food security and local livelihoods (Hussain et al. 2018; Manandhar et al. 2011),. In study areas, outmigration of active household members is adding to both challenges and opportunities for the local communities. One option to improve income is through remittances. However, in some cases, it is also adding to the challenges of local communities. In Gatlang, out-migration of active male household members resulted in labour shortages in agriculture with an increase in the agricultural labour burden on women. However, such labour shortages were not reported from other study sites. In Thuman and Chilime, increasing local economic opportunities are reducing the extent of out-migration. It is always important to identify emerging local economic opportunities which allow the retention of the economically active section of the population in the area (Rasul et al. 2014).

Local people are gradually diversifying their income sources. They have enhanced their involvement in off-farm income sources such as tourist services, handcrafts, and employment in local resorts, and in the cheese factory and hydro power station (Table 2). However, a significant proportion of households in the study sites still depend heavily on agriculture and livestock for their food security and livelihood. In Gatlang, this is the case with almost $70 \%$ of the households, as reported by the local community. Agriculture is highly vulnerable to climatic changes, as found in other mountain areas of Nepal (Hussain et al. 2016, 2018). Local communities perceived changes in climatic factors. These include changes in the availability of water (too much or too little), growing risks of landslides, and impacts of rising temperatures. Water availability is already being affected by rising temperatures, leading to more rapid melting of snow, reductions in snowfall or its replacement by rainfall, and increasingly erratic rainfall. The latter includes a possible increase in the incidence of drought, compounded by more severe events such as hailstorms and extremely heavy rainfall. The water storage function of glaciers and heavy snowfall is diminishing, leading to more seasonal flash flooding and an increase in erosion and landslides. These changes in climatic factors are consistent with those found in other mountain areas of Nepal by various studies (Manandhar et al. 2011; Chhetri et al. 2012; Holmelin and Aase 2013; Aryal et al. 2016; Pradhan et al. 2015).

The impacts of climate change on crops are mixed to date: having both positive and negative impacts. In Gatlang, the productivity of potato and barley increased in years 2015 and 2016 with changes in precipitation patterns. However, erratic precipitation resulted in a lower production of potato and barley during 2010-2014. In Goljung, changes in rainfall patterns, increased number of foggy days and hailstorms have negatively affected the productivity of almost all crops (Table 6). There is also an increase in the incidence of pest attacks on crops. Similarly, in Chilime, Grey and Thuman, local people reported a decline in crop productivity, due mainly to changing rainfall patterns.

It is difficult to attribute coping and adaptation actions taken by local communities solely to climatic factors. The coping and adaptation mechanisms discussed here were driven by multiple factors, including better income opportunities, water scarcity, labour shortages, and climatic variability and change. Farmers are diversifying their agriculture systems through expanding the cultivation of traditional food crops (e.g. millets, barley and pulses), and integrating vegetables and livestock with existing crops. Livestock particularly chauri has been integrated into agriculture systems in response to milk demand from a locally established cheese factory (see Box 1). Farmers perceived that traditional food crops were more resilient to water and cold wave stresses. A recent study (Adhikari et al. 2017) reported that farmers in Gatlang preferred to cultivate traditional crops because of growing demand from local resorts. In Gatlang, Chilme and Grey, farmers are also improving their irrigation methods to support the diversification of their agriculture systems. Our study reports the improvements of irrigation methods, both traditional small-scale gravity schemes for rice and newer systems of vegetable production with drip irrigation under plastic tunnels. But, we also found considerable evidence of growing pressures and even conflicts that exist. Mostly informal and institutional mechanisms of water management are struggling to manage. The irrigation- 
hydropower conflict may be minimized through best practices in benefit sharing that are being implemented in other hydropower projects in Nepal. Examples include equity investments in hydropower projects, support for local livelihoods and community development, and negotiations for priority allocation of water during peak agricultural demand periods (see ICIMOD 2016).

We also identified potential and opportunities which can considered as future directions for achieving food security and livelihoods in the study areas. One example of a new opportunity is the growing potential for producing and profitably marketing high-value vegetables, both locally and for urban markets (especially in Chilime). Locally, the current and anticipated investments in hydropower are creating employment opportunities and a market for quality vegetables. This is complemented by a growing tourist trade. And, if tourist facilities are upgraded, wealthier tourists may be attracted to the area, increasing the demand for vegetables and other local products such as traditional food crops and handicrafts. There is also a growing market demand in Rasuwa District towns such as Syabrubesi and Dhunche, and if the road network is improved, more produce may be profitably sold in distant cities including Kathmandu. The use of plastic tunnels to grow vegetables is only beginning in this area, but is likely to grow, possibly complemented by low-cost solar pumps. There is need for the government to promote tunnel farming and such solar pumps.

Another important economic opportunity relates to the sale of cash crops such as potato and barley (traditional crop), as reported by Szabo et al. (2018) from the same areas. New varieties are becoming available that are more productive and command higher prices. Investing in strengthening the entire value chain from production and harvesting to packaging, transporting, and marketing has the potential to increase farmers' incomes. Value chain development may also be a good solution to improving income from traditional food crops (Adhikari et al. 2017).

Raising livestock, and selling both live animals and milk are very important sources of income and are increasing. Locals believe pastures are less affected by climate change than crop production, though there are studies that suggest warming temperatures are leading to changes in grass species and the introduction of alien species in higher-altitude pastures (Aryal et al. 2016).

\section{Conclusions}

Around 240 million people live in the Hindu-Kush Himalayan (HKH) mountain areas (Rasul et al. 2018). In this region, the food security and livelihoods of mountain communities depend heavily on agriculture and livestock, despite the growing importance of off-farm income sources such as remittances, small businesses, wage labour, tourism, handcrafts (Hussain et al. 2016, 2018; Rasul et al. 2014). Socioeconomic and climatic changes are adding to the challenges to agriculturedependent food security and livelihoods. High altitude study areas, e.g. Gatlang, Goljung, Chilime, Thuman and Grey, of Rasuwa district, Nepal are no exception where half of the population is food poor, and half of the children below 5 years are stunted. Despite being one of the main income generating options, outmigration of active male populations may result in labour shortages in agriculture with an increase in the agricultural labour burden falling on women, particularly in Gatlang VDC. However, arising local economic opportunities are reducing the extent of out-migration. Local people reported changes in climatic factors, e.g. precipitation patterns and temperature, and increased incidence of extreme events, e.g. erratic rainfall and hailstorm. Climate change has both positive and negative impacts on agriculture. Local people are taking autonomous adaptation actions to cope with the negative impacts of climate change in agriculture. These actions include diversification of agriculture systems through enhancing the cultivation of traditional food crops (e.g. millets, barley and pulses), and integration of vegetables and livestock with existing crops, and improvement of irrigation methods.

The study identified the following potential and opportunities of people in these high mountain areas to improve food security and livelihoods:

- It is important to capitalize on the growing potential for producing and profitably marketing high-value vegetables, climate resilient traditional food crops and handcrafts, both locally and in urban markets (especially in Chilime, Syabrubesi and Dhunche). Locally, inflow of employees in the local hydropower station, and increasing numbers of tourists are creating a market for quality vegetables. If the road network is improved, more produce may be profitably sold in distant cities including Kathmandu.

- In response to growing demand for vegetables, local farmers have installed plastic tunnels to grow them. Government support is needed to complement plastic tunnels with low-cost solar pumps, and promote this integrated technology that may improve resilience of farmers to climate change with less dependence on rainfall, and reduced exposure of vegetables to erratic events, e.g. hailstorms, heavy rainfall, and cold waves.

- There is huge scope for improving local water management practices. Irrigation systems are expanding but these are mainly managed through informal institutional mechanisms. Local communities reported conflicts over water distribution and use. There is need to formalize the management of existing irrigation systems, particularly in Chilime and Thuman VDCs. 
- There is also a need to build capacity of farmers and local traders by value chain development of vegetables, traditional crops and handcrafts to increase farmers' incomes (Adhikari et al. 2017).

- The government may support the livestock sector in these mountain areas through improving veterinary services and establishing more milk collection centres. Local communities reported that pastures are less affected by climate change than crop production. In the study areas, livestock is mainly dependent on pastures. More importantly, a success story of income improvement from sale of chauri milk in Gatlang is already reported in this study.

Acknowledgements The study was carried out by the Himalayan Adaptation, Water and Resilience (HI-AWARE) consortium under the Collaborative Adaptation Research Initiative in Africa and Asia (CARIAA), with financial support from the United Kingdom's
Department for International Development (DFID) and the International Development Research Centre (IDRC), Canada.

This study was also partially supported by core funds of ICIMOD contributed by the governments of Afghanistan, Australia, Austria, Bangladesh, Bhutan, China, India, Myanmar, Nepal, Norway, Pakistan, Sweden and Switzerland. We are also very grateful to Dr. Vishwas S. Chitale (remote sensing analyst, ICIMOD) for mapping the study sites.

Finally, we should like to express our deepest appreciation of the assistance of local contact persons during the field data collection, and of all local informants who took precious time to share their insights and knowledge. We are ultimately solely responsible for the contents of the paper.

The views expressed in this work are those of the authors and do not necessarily represent those of DFID, IDRC or its Board of Governors. In addition, they are not necessarily attributable to authors' organizations.

\section{Compliance with ethical standards}

Conflict of interest The authors declare that they have no conflict of interest.

\section{Appendix}

Table 7 Coordination schema

\begin{tabular}{|c|c|c|c|}
\hline Specific objectives of study & Required information & Data source & Data collection method \\
\hline $\begin{array}{l}\text { To collect basic socioeconomic } \\
\text { information about Rasuwa } \\
\text { district and study areas, i.e. } \\
\text { Gatlang, Goljung, Chilime, } \\
\text { Thuman and Grey }\end{array}$ & $\begin{array}{l}\text { - Location and altitude } \\
\text { - Climatic factors } \\
\text { - Food and nutrition security }\end{array}$ & $\begin{array}{l}\text { - Published literature } \\
\text { - District Agriculture } \\
\text { Development Office } \\
\text { (DADO) }\end{array}$ & $\begin{array}{l}\text { Recorded from published } \\
\text { literature and government } \\
\text { reports. }\end{array}$ \\
\hline $\begin{array}{l}\text { To understand the livelihood } \\
\text { systems } \\
\text { of the local communities. }\end{array}$ & $\begin{array}{l}\text { - Livelihood sources (farm and non-farm) } \\
\text { - Trends in livelihood activities } \\
\text { - Socioeconomic changes } \\
\text { - Case studies of some key livelihood } \\
\text { activities (chauri milk sale and vegetable } \\
\text { production group) }\end{array}$ & $\begin{array}{l}\text { - Focus group discussions } \\
\text { (FGDs) with local people } \\
\text { - Key informants } \\
\text { - Field Observations }\end{array}$ & $\begin{array}{l}\text { - Non-structured checklists } \\
\text { - Open discussions without } \\
\text { specific guideline } \\
\text { (documenting case studies }\end{array}$ \\
\hline $\begin{array}{l}\text { To understand the agriculture } \\
\text { systems } \\
\text { and water resources }\end{array}$ & $\begin{array}{l}\text { - Types of crops } \\
\text { - Types of livestock } \\
\text { - Water resources } \\
\text { - Irrigation system/scheme } \\
\text { - Sources of water in irrigation systems } \\
\text { - Challenges in water management } \\
\text { - Potential/scope to improve water } \\
\text { management } \\
\text { - Documentation of case studies of farmer } \\
\text { managed irrigation systems }\end{array}$ & $\begin{array}{l}\text { - Focus group discussions } \\
\text { (FGDs) with local people } \\
\text { - Key informants } \\
\text { - Field Observations } \\
\text { - District irrigation Office }\end{array}$ & $\begin{array}{l}\text { - Non-structured checklists } \\
\text { - Open discussions without } \\
\text { specific guideline } \\
\text { (documenting case studies }\end{array}$ \\
\hline $\begin{array}{l}\text { To study local people's } \\
\text { perception of climate change }\end{array}$ & $\begin{array}{l}\text { Local people's opinion on changes in } \\
\text { following climatic aspects (compared to } \\
10 \text { years before). } \\
\text { - Precipitation patterns } \\
\text { - Temperature } \\
\text { - Timing of seasons } \\
\text { - Climate induced extreme events (e.g. } \\
\text { droughts, floods, hailstorms) } \\
\text { - Incidence of insect and pest attacks }\end{array}$ & $\begin{array}{l}\text { - Focus group discussions } \\
\text { (FGDs) with local people } \\
\text { - Key informants }\end{array}$ & $\begin{array}{l}\text { - Non-structured checklists } \\
\text { - Open discussions without } \\
\text { specific guideline }\end{array}$ \\
\hline $\begin{array}{l}\text { To assess the impacts of climatic } \\
\text { and socioeconomic changes on }\end{array}$ & $\begin{array}{l}\text { Discussion on climate change impacts on } \\
\text { the following aspects. } \\
\text { - Water availability for agriculture }\end{array}$ & $\begin{array}{l}\text { - Focus group discussions } \\
\text { (FGDs) with local people } \\
\text { - Key informants }\end{array}$ & $\begin{array}{l}\text { - Non-structured checklists } \\
\text { - Open discussions without } \\
\text { specific guideline }\end{array}$ \\
\hline
\end{tabular}


Table 7 (continued)

\begin{tabular}{|c|c|c|c|}
\hline Specific objectives of study & Required information & Data source & Data collection method \\
\hline $\begin{array}{l}\text { water resources, agriculture } \\
\text { and livelihoods }\end{array}$ & $\begin{array}{l}\text { - Productivity of major and minor crops } \\
\text { - Specific changes in climatic factors } \\
\text { which affect crop productivity } \\
\text { - Pastures, grasslands and livestock } \\
\text { - Water access through irrigation systems }\end{array}$ & & \\
\hline $\begin{array}{l}\text { To examine and document the } \\
\text { adaptation measures taken by } \\
\text { local people to cope with the } \\
\text { changes. }\end{array}$ & $\begin{array}{l}\text { - Measures of cropping patterns } \\
\text { - Measures of water use practices } \\
\text { - Measures of livestock raising } \\
\text { - Emerging measures/opportunities in } \\
\text { crops and livestock } \\
\text { - Emerging measures/opportunities in } \\
\text { off-farm activities. }\end{array}$ & $\begin{array}{l}\text { - Focus group discussions } \\
\text { (FGDs) with local people } \\
\text { - Key informants } \\
\text { - District Agriculture } \\
\text { Development Office } \\
\text { (DADO) }\end{array}$ & $\begin{array}{l}\text { - Non-structured checklists } \\
\text { - Open discussions without } \\
\text { specific guideline }\end{array}$ \\
\hline
\end{tabular}

Open Access This article is distributed under the terms of the Creative Commons Attribution 4.0 International License (http:// creativecommons.org/licenses/by/4.0/), which permits unrestricted use, distribution, and reproduction in any medium, provided you give appropriate credit to the original author(s) and the source, provide a link to the Creative Commons license, and indicate if changes were made.

\section{References}

Adhikari, L., Hussain, A., \& Rasul, G. (2017). Tapping the potential of neglected and underutilized food crops for sustainable nutrition security in the mountains of Pakistan and Nepal. Sustainability, 9(2), 291. https://doi.org/10.3390/su9020291.

Aryal, S., Cockfield, G., \& Maraseni, T. N. (2016). Perceived changes in climatic variables and impacts on the transhumance system in the Himalayas. Climate and Development, 8(5), 435-446. https://doi. org/10.1080/17565529.2015.1040718.

Baul, T. K., Atique Ullah, K. M., Tiwari, K. R., \& McDonald, M. A. (2013). People's local knowledge of climate change in the MiddleHills of Nepal. Indian Journal of Traditional Knowledge, 12(4), 585-595.

Bolch, T., Kulkarni, A., Kääb, A., Huggel, C., Paul, F., Cogley, J. G., Frey, H., Kargel, J. S., Fujita, K., Scheel, M., \& Bajracharya, S. (2012). The state and fate of Himalayan glaciers. Science, 336(6079), 310-314.

@@@

Chaudhary, P., \& Bawa, K. S. (2011). Local perceptions of climate change validated by scientific evidence in the Himalayas. Biology Letters, 7, 767-770. https://doi.org/10.1098/rsbl.2011. 0269.

Chaudhary, P., Rai, S., Wangdi, S., Mao, A., Rehman, N., Chettri, S., \& Bawa, K. S. (2011). Consistency of local perceptions of climate change in the Kangchenjunga Himalaya landscape. Current Science, 101(4, 25), 504-513.

Chhetri, N., Chaudhary, P., Tiwari, P. R., \& Yadaw, R. B. (2012). Institutional and technological innovation: understanding agricultural adaptation to climate change in Nepal. Applied Geography, 33, 142-150. https://doi.org/10.1016/j.apgeog. 2011.10.006.

Crate, S.A., \& Nuttall, M. (Eds.) (2009). Introduction: Anthropology and climate change. In Anthropology and climate change: From encounters to actions (1st edn, pp. 9-36). Routledge. ISBN-13: 9781598743340.
Gawith, D., Hill, D., \& Kingston, D. (2015). Determinants of vulnerability to the hydrological effects of climate change in rural communities: evidence from Nepal. Climate and Development, 9(1), 50-65. https://doi.org/10.1080/17565529.2015.1067184.

Gentle, P., \& Maraseni, T. N. (2012). Climate change, poverty and livelihoods: adaptation practices by rural mountain communities in Nepal. Environmental Science and Policy, 21, 24-34.

Gerlitz, J. Y., Hunzai, K., \& Hoermann, B. (2012). Mountain poverty in the Hindu-Kush Himalayas. Canadian Journal of Development Studies/Revue Canadienne d'études du développement, 33(2), 250-265. https://doi.org/10.1080/ 02255189.2012.689613.

Gerlitz, J. Y., Apablaza, M., Hoermann, B., Hunzai, K., \& Bennett, L. (2015). A multidimensional poverty measure for the Hindu KushHimalayas, applied to selected districts in Nepal. Mountain Research and Development, 35(3), 278-288. https://doi.org/10. 1659/MRD-JOURNAL-D-14-00027.1/.

Government of Nepal (GoN) and World Food Programme (WFP) (2016). The Nepal Food Security Monitoring System (Nepal Khadhya Surakshya Anugaman Pranali (NeKSAP)). The Ministry of Agricultural Development (MoAD) and the National Planning Commission (NPC), Government of Nepal, and World Food Programme, Kathmandu.

Haslett, S., Jones, G., Isidro, M., \& Sefton, A. (2014). Small area estimation of food insecurity and undernutrition in Nepal, Central Bureau of Statistics, National Planning Commissions Secretariat, World Food Programme, UNICEF and World Bank, Kathmandu, Nepal.

Holmelin, N., \& Aase, T. H. (2013). Flexibility of scope, type and temporality in mustang, Nepal. Opportunities for adaptation in a farming system facing climatic and market uncertainty. Sustainability, 5, 1387-1405. https://doi.org/10.3390/su5041387.

Hunzai, K., Gerlitz, J. Y., \& Hoermann, B. (2011). Understanding mountain poverty in the Hindu Kush-Himalayas: Regional report for Afghanistan, Bangladesh, Bhutan, China, India, Myanmar, Nepal, and Pakistan. Kathmandu: ICIMOD.

Hussain, A., Rasul, G., Mahapatra, B., \& Tuladhar, S. (2016). Household food security in the face of climate change in the Hindu-Kush Himalayan region. Food Security, 8(5), 921-937.

Hussain, A., Rasul, G., Mahapatra, B., Wahid, S., \& Tuladhar, S. (2018). Climate change-induced hazards and local adaptations in agriculture: a study from Koshi River basin, Nepal. Natural Hazards, 91(3), 1365-1383.

ICIMOD (International Center for Integrated Mountain Development) (2016). Benefit sharing and sustainable hydropower in Nepal: Key highlights. Kathmandu: International Centre for Integrated 
Mountain Development \& Niti Foundation. http://lib.icimod.org/ record/32027/files/icimodHydropower.pdf.

Immerzeel, W. W., Pellicciotti, F., \& Bierkens, M. F. P. (2013). Rising river flows throughout the twenty-first century in two Himalayan glacierized watersheds. Nature Geoscience, 6, 742-745. https:// doi.org/10.1038/NGEO1896.

Immerzeel, W. W., Petersen, L., Ragettli, S., \& Pellicciotti, F. (2014). The importance of observed gradients of air temperature and precipitation for modeling runoff from a glacierized watershed in the Nepalese Himalayas. AGU Water Resources Research, 48, 2212 2226. https://doi.org/10.1002/2013WR014506.

Kusters, K., \& Wangdi, N. (2013). The costs of adaptation: changes in water availability and farmers' responses in Punakha district, Bhutan. International Journal of Global Warming, 5(4), 387-399.

Lutz, A. F., Immerzeel, W. W., Shrestha, A. B., \& Bierkens, M. F. P. (2014). Consistent increase in high Asia's runoff due to increasing glacier melt and precipitation. Nature Climate Change, 4, 587-592. https://doi.org/10.1038/NCLIMATE2237.

Macchi, M., Gurung, A. M., Hoermann, B., \& Choudhary, D. (2011). Climate variability and change in the Himalayas: Community perceptions and responses. Kathmandu: ICIMOD.

Manandhar, S., Vogt, D. S., Perret, S. R., \& Kazama, F. (2011). Adapting cropping systems to climate change in Nepal: a cross-regional study of farmers' perception and practices. Regional Environmental Change, 11, 335-348. https://doi.org/10.1007/s10113-010-0137-1.

McNamara, K.E., \& Buggy. L. (2017). Community-based climate change adaptation: a review of academic literature, Local Environment, 22(4), 443-460.

McVeigh, C. (2004). Himalayan herding is alive and well: The economics of pastoralism in the Langtang Valley. Nomadic Peoples, new series, 8(2): 107-124. Special issue: Whither south Asian pastoralism? Online: White horse press. http://www.jstor.org/stable/43123727? seq=1\#page_scan_tab_contents.

Neupane, P. K., \& Devkota, B. (2017). A brief report on climate change awareness program and consultation cum interaction program on climate change knowledge management. Kathmandu: Nepal Academy of Science and Technology.

NPHC (National Population and Housing Census). (2011). Village development committee/municipality. Kathmandu: Central Bureau of Statistics, National Planning Commission Secretariat, Government of Nepal.

Pradhan, N. S., Sijapati, S., \& Bajracharya, S. R. (2015). Farmers' responses to climate change impact on water availability: insights from the Indrawati Basin in Nepal. International Journal of Water Resources Development, 31(2), 269-283. https://doi.org/10.1080/ 07900627.2015 .1033514$.

Rasul, G., \& Hussain, A. (2015). Sustainable food security in the mountains of Pakistan: towards a policy framework. Ecology of Food and Nutrition, 54(6), 625-643.

Rasul, G., Hussain, A., Khan, M.A., Ahmad, F., Jasra, A.W. (2014). Towards a framework for achieving food security in the mountains of Pakistan. ICIMOD working paper 2014/5. Kathmandu: ICIMOD.

Rasul, G., Sharma, B., Mishra, B., Neupane, N., Dorji, T., Khadka, M. S., \& Joshi, S. R. (2015). Strategic framework for resilient livelihoods in earthquake-affected areas of Nepal. Kathmandu: International Centre for Integrated Mountain Development (ICIMOD) ISBN 9789291153473.

Rasul, G., Saboor, A., Tiwari, P., Hussain, A., Ghosh, N., Chettri, G., et al. (2018). Chapter 9- food and nutrition security in the HKH. In: Hindu Kush Himalayan Monitoring and Assessment Programme (HIMAP) (forthcoming). Kathmandu: International Centre for Integrated Mountain Development (ICIMOD).

Rudiak-Gould, P. (2011). Climate change and anthropology: the importance of reception studies. Anthropology Today, 27(2): 9-12. Respond to this article at http://www.therai.org.uk/at/ debate.
Shrestha, U. B., Gautam, S., \& Bawa, K. S. (2012). Widespread climate change in the Himalayas and associated changes in local ecosystems. PLoS One, 7(5), e36741. https://doi.org/10.1371/journal.pone. 0036741.

Shrestha, A. B., Agrawal, N. K., Alfthan, B., Bajracharya, S. R., Maréchal, J., \& van Oort, B. (Eds.). (2015). The Himalayan climate and water atlas: Impact of climate change on water resources in five of Asia's major river basins. ICIMOD, GRID-Arendal and CICERO: Kathmandu.

Sujakhu, N. M., Ranjitkar, S., Niraula, R. R., Pokharel, B. K., SchmidtVogt, D., \& Xu, J. (2016). Farmers' perceptions of and adaptations to changing climate in the Melamchi Valley of Nepal. Mountain Research and Development, 36(1), 15-30. https://doi.org/10.1659/ MRD-JOURNAL-D-15-00032.1.

Szabo, S., Hossain, M., Renaud, F., Traore, D., Hussain, A., Matczak, P., Ahmad, S., Singh, D. R., Neumann, B., \& Matthews, Z. (2018). Accelerating progress towards the zero hunger goal in crossboundary climate change hotspots. Environment: Science and Policy for Sustainable Development, 60(3), 18-27.

Tamang, D.D. (2016). A study on socioeconomic conditions and drivers leading to vulnerabilities in upstream of Gandaki Basin: A case of Rasuwa District. Submitted to HI-AWAREICIMOD. SEARCH-Nepal. Final Report. Unpublished. 20 December 2016.

Wang, J., Wang, Y., Li, S., \& Qin, D. (2016). Climate adaptation, institutional change, and sustainable livelihoods of herder communities in northern Tibet. Ecology and Society, 21(1), 5. https://doi.org/10. 5751/ES-08170-210105.

Wiltshire, A. J. (2014). Climate change implications for the glaciers of the Hindu Kush, Karakoram and Himalayan region. The Cryosphere, 8, 941-958. https://doi.org/10.5194/tc-8-941-2014.

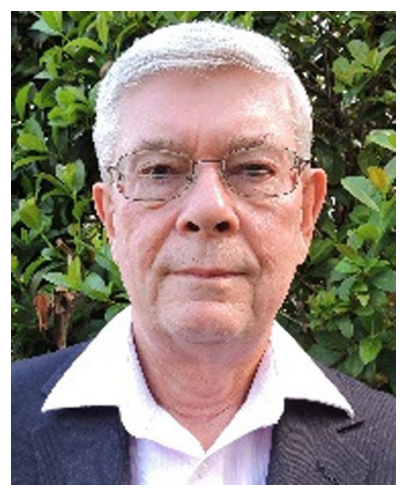

Dr. Douglas James Merrey is Natural Resources Policy and Institutions Specialist. Based in Florida, USA, he works as an independent consultant. He has nearly 40 years of experience working and living in developing countries in Asia and Africa. For over 20 years he was employed by the International Water Management Institute (IWMI) where he held increasingly significant leadership positions. These included being the founding Director for Africa. Doug holds a Ph.D. in anthropology. From the beginning of his career he has worked in multi-disciplinary multi-cultural teams. His early field research focused on local management of irrigation schemes, but over time he has worked increasingly on national water management policies and institutional reform, and national and international river basin management. He has a substantial record of publications in international journals combined with practical advisory experience. Working as an independent consultant since 2008, his clients have included IFAD, World Bank, IWMI, ILRI, CIAT, Challenge Program on Water and Food (CPWF), the CGIAR Standing Panel on Impact Assessment (SPIA), FANRPAN, Euroconsult Mott MacDonald, and Abt Associates. 


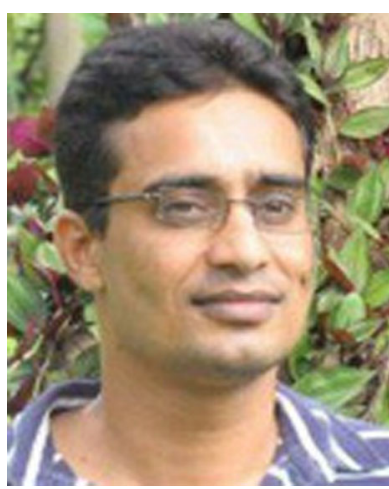

r. Abid Hussain, a Pakistani national, joined International Centre for Integrated Mountain Development (ICIMOD), Nepal, in December 2013 as a Food Security Economist. Prior to joining ICIMOD, he served as Assistant Professor at the Department of Economics in the University of Haripur, Khyber Pakhtunkhwa, Pakistan. He also served in the same position in the Department of Economics and Agricultural Economics at Pir Mehr Ali Shah Arid Agriculture University, Rawalpindi, Pakistan. He was responsible for teaching advanced economics courses to MPhil and $\mathrm{PhD}$ students. $\mathrm{He}$ also supervised the research of postgraduate students who were mainly working in the areas of agriculture and food security, energy conservation and women empowerment. Dr. Hussain holds a $\mathrm{PhD}$ in Regional and Rural Development Planning (RRDP) from the Asian Institute of Technology (AIT), Thailand. From same institute, he had earlier earned a master's degree in RRDP. Dr. Hussain also has a bachelor's degree in Agricultural Economics from the University of Agriculture, Faisalabad (UAF), Pakistan. Dr. Hussain has been working on food security and poverty issues for more than 6 years in different capacities in different organizations. His areas of expertise include food and nutrition security, agricultural credit, poverty, smallholder farming, and conservation agriculture. His research findings have been published in reputed international journals.

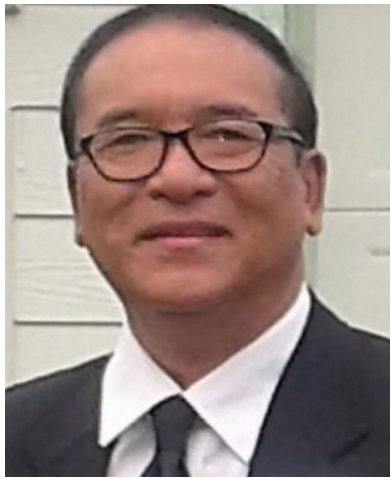

Mr. Deepak Dorje Tamang is the Director of SEARCH, Nepal, which is a Non-Government Development Organization (NGDO). He possesses 37 years invaluable experience in development, environment and capacity building in Nepal; Asia wide; Europe and USA. He started his career as a Project Officer for UNICEF in Water and Environmental Sanitation. He served as a Program Officer for Swiss Development Cooperation (SDC) and Swiss Development Assistance (Helvetas) in Nepal. He subsequently served as the Program Coordinator for a livelihood program of the SDC and GTZ in Nepal. He also served as the Senior Technical Advisor in building capacity for a CIDA supported integrated development project in western Nepal. $\mathrm{He}$ started a development and environment NGDO in Nepal called SEARCH in 1989. Since then he has served as the Director and Founding Member. As a professional member of SEARCH, he has worked in many countries globally as a strategic planner; trainer and facilitator; researcher; project manager and team leader for a number of important projects. In the last three decades, he has led many projects related to impact monitoring; evaluation; building capacity; learning organization and peace initiatives. He has also worked extensively in integrated community development with emphasis on building capacity for community organizations and NGDOs. He has worked closely with the Human Settlements Division of the Asian Institute of Technology (AIT)Bangkok and many NGDOs in Asia to develop management courses for the NGDOs. As a British Council Fellow in UK, he studied Organizational Management at Cranfield University (Cranfield Institute of Technology - Bedford). He was a World Forestry Fellow in Portland, Oregon, USA and researched on forest management; climate change and global warming; riparian management and alternative biomass fuels. $\mathrm{He}$ was also the Adjunct Professor - Guest Faculty, College of Forestry and Environmental Sciences, Oregon State University (OSU) - Corvallis. Currently, he serves as the Director of SEARCH and Senior Institutional Capacity Development Adviser/Consultant to UNDP's Micro-Enterprise Development Programme (MEDEP). He is also a senior researcher with HI-AWARE/ICIMOD for upstream Rasuwa.

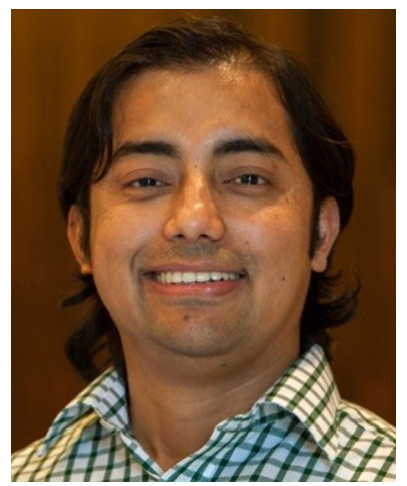

Mr. Bhuwan Thapa is a $\mathrm{PhD}$ Candidate in the School of Geography and Development, University of Arizona, Tucson, USA. He is doing his $\mathrm{PhD}$ under Himalayan Adaptation, Water and Resilience (HI-AWARE) programme of International Centre for Integrated Mountain Development (ICIMOD), Nepal. Thapa's research focuses on the resilience of irrigated agriculture, especially farmer-managed irrigation systems, against changing climate in the Gandaki River

Basin in Nepal. He will evaluate the biophysical and social vulnerabilities affecting the farmers and assess the effectiveness of their responses and adaptation interventions against multiple objectives like their ability to strengthen system resilience, address livelihood and environmental securities, and achieve gender equity. The study field tests many important adaptation concepts like ecological and social thresholds, institutional adaptive capacity, and turning and tipping points. Evidence from these emprical studies will expand the knowledge base of climate adaptation literature and provide useful information to adaptation practitioners and policymakers. Prior to joining the $\mathrm{PhD}$ programme, he was a water resources management consultant, working on the Bagmati River Basin planning and management programmes for Japan Water Agency and Danish Hydraulic Institute. He has worked for institutions such as the World Wildlife Fund (Nepal), WaterAid (Nepal), the Center for Clean Air Policy (USA) and A4 Scientific (USA) in areas such as water and sanitation, decentralised wastewater systems, instrumental pollutant analysis, climate change and modelling, community forestry, and environmental impact assessment. He holds a Master's degree in Public Policy from the University of Maryland, College Park. 


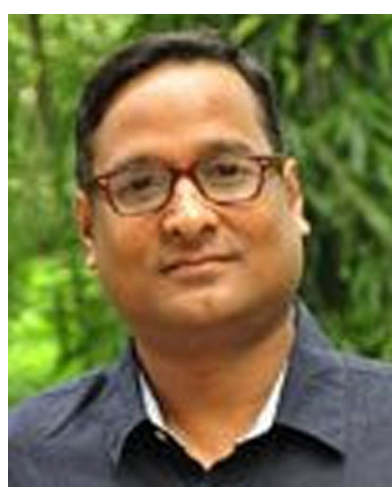

Dr. Anjal Prakash is the Programme Coordinator of Himalayan Adaptation, Water and Resilience (HI-AWARE) Research on Glacier and Snowpack Dependent River Basins at the International Center for Integrated Mountain Development (ICIMOD) based in Kathmandu, Nepal. HIAWARE is a special initiative that focuses on adaptation issues in three river basins of South Asia. Dr. Prakash has been selected as coordinating lead author for the

IPCC Special Report on the Ocean and Cryosphere in a Changing Climate (SROCC) to be finalized in September 2019. Before joining ICIMOD, Dr. Prakash led the South Asia Consortium for Interdisciplinary Water Resources Studies (SaciWATERs) that worked in six countries of South Asia. Having an advanced degree (1997) from the Tata Institute and Social Sciences (TISS), Mumbai, India and a PhD (2005) in Social/Environmental Sciences from Wageningen University, The Netherlands, Dr. Prakash has been working in the area of policy research, advocacy, capacity building, knowledge management, networking and implementation of large scale and multi-country environmental development projects in South Asia. Dr. Prakash is the author of The Dark Zone: Groundwater Irrigation, Politics and Social Power in North Gujarat (2005), published by Orient Longman. His recent co-edited books are Interlacing Water and Health: Case Studies from South Asia (2012) published by Sage and Water Resources Policies in South Asia (2013), Globalization of Water Governance in South Asia (2013), Informing Water Policies in South Asia (2014) published by Routledge, Gender Issues in Water and Sanitation Programmes: Lessons from India, published by Sage (2015) and Periurban water security issues in South Asia to be published by Oxford University Press (2016). 